\title{
Mother's Parenting with an Unplanned Pregnancy Status in Maintaining the Health of Toddlers
}

\author{
Choirul Anna Nur Afifah, Veni Indrawati, Niken Purwidiani \\ Department of Home Economics \\ Universitas Negeri Surabaya \\ Surabaya, Indonesia \\ choirulanna@unesa.ac.id
}

\begin{abstract}
The objectives of this study were to identify health and nutritional knowledge of mothers, mother's behavior in caring toddler health, and to analyze pregnancy intentions with mother's behaviors in caring toddlers' health. The data of descriptive quantitative research were collected through cognitive test, interviews, and analyzed by Spearman's rho and ttest. Results showed that mothers' nutrition and health knowledge are categorized as fair. The mothers' behaviors of caring toddler health are categorized as good. Mothers with planned pregnancy provided breastfeeding and complementary feeding are better than those with unplanned pregnancy. However, there was no correlation between pregnancy status and mother's behavior.
\end{abstract}

Keywords-mother's behavior; pregnancy status; health; toddler

\section{INTRODUCTION}

Toddler health is strongly influenced by the role of a mother. A mother plays an essential role from preparing a pregnancy to maintaining the health of a toddler after being born. Unplanned pregnancy cases include pregnancy among teenagers due to an unmarried relationship (premarital sex) and unwanted pregnancy to a married couple.

Unplanned pregnancy conditions provide risks and problems for mothers, toddlers and other family members. Unplanned pregnancy conditions certainly provide risks and problems for mothers, toddlers and other family members. Unwanted pregnancy will encourage miscarriage or abortion, low birth weight and premature birth. This of course also affects the increased risk for maternal and child mortality. Unplanned pregnancy is also at risk of depression in the mother [1]. Pregnant mothers with uncomfortable mental or psychological fitness are closely related to inadequate antenatal care and maternal pregnancy complications that may result in increased maternal and infant morbidity and mortality [1,2]. Complications of pregnancy include excessive nausea, vomiting (hyperemesis gravdiarum), preeclampsia, bleeding and pregnancy-induced illnesses, among others, psychiatric disorders. Several studies have shown that hyperemesis gravdiarum is a mother's unconscious effort as a form of rejection of pregnancy experienced $[3,4]$.

Every year, an estimates 80 million women have unwanted or unintended pregnancies, and 45 million of which are terminated [4]. Indonesia Demographic and Health Survey 2012 (SDKI 2012) was found that $7 \%$ of birth are expected later and $7 \%$ of births are not desirable at all [5]. Mothers with unwanted pregnancies have a tendency not to have their pregnancies checked for competent health personnel, inadequate immunization and improper breastfeeding behavior. LISREL analyses based on the 1991 Peruvian Demographic and Health Survey (DHS) indicated there was association breast-feeding duration with pregnancy intentions [6]. However, no information has been obtained regarding the relationship of maternal pregnancy status with the mother's behaviors in caring toddlers'. It is therefore necessary to know whether or not there is a link between the mother and the planned and unplanned pregnancy with the mother's behavior to maintain the health of toddler. Maternal behavior examined included breastfeeding, complementary feeding, and immunization.

\section{METHOD}

The research design was cross sectional study. The study was conducted in Pasuruan, East Java, Indonesia. The respondents were 17 -year-old mother to mother at age 45 with children from 0 to 24 months. The number of respondents is thirty four mothers. Consist of fifteen mothers with planned pregnancy status and nineteen mothers with unplanned pregnancy status.

Information was collected on socioeconomic variable; numbers of family, education level, family income per month; nutritional status of toddlers; and mother behavior in caring toddlers' health. Maternal behavior observed included breastfeeding, complementary food, immunization and health care of toddlers. The data were collected using interview technique and test.

The number of family members was divided into small families ( $<4$ persons), moderate $(5-7$ persons) and large $(>7$ people). Mother education was measured by the length of school, categorized into lower education ( $<6$ years), secondary education (7-12 years) and higher education (> 12 years). Family income was derived from the total exposure of all family members per month grouped into low (X <x-1SD), moderate $(x-1 S D<X<x+1 S D)$ and high $(X>x+1 S D)$. 
Mother's nutritional knowledge was assessed from the total score of answers to 22 questions. Nutrition knowledge was grouped to be poor $(<60 \%$ correct answer), fair $(60-80 \%$ correct answer), and good ( $>80 \%$ correct answer). Mother's behavior was distinguished to be good, fair and less good. Spearman's rho was done to analyzed association between variable. T-test was used to know the difference of variable from pregnancy intentions (planned vs. unplanned).

\section{RESULT AND DISCUSSION}

\section{A. Socioeconomic characteristics}

Unplanned pregnancy was occurred because unmarried relationship (premarital sex) $(26.3 \%)$, maternal age over 35 years $(31.6 \%)$ and the birth spacing was too close $(42.1 \%)$. The majority of mothers have small family $\leq 4$ people $(78.9 \%)$. Of the mother in this study, $20.6 \%$ had higher education. About $70.6 \%$ mothers did not work or housewife. The respondent's family income per month ranges from IDR 400.000,00 to IDR $3,532,750.00$ with an average of IDR 1.702.607,00 \pm IDR $1.312 .822,74$. The majority of respondents' family income is moderate, as much as $91.3 \%$.

TABLE I. SOCIOECONOMICS CHARACTERISTICS OF RESPONDENT

\begin{tabular}{|l|c|c|c|c|}
\hline \multirow{2}{*}{ Socioeconomic aspects } & \multicolumn{2}{c|}{$\begin{array}{c}\text { Unplanned } \\
\text { pregnancy }\end{array}$} & \multicolumn{2}{c|}{$\begin{array}{c}\text { Planned } \\
\text { Pregnancy }\end{array}$} \\
\cline { 2 - 5 } & $\boldsymbol{n}$ & $\boldsymbol{\%}$ & $\boldsymbol{n}$ & $\%$ \\
\hline Members of family & & & & \\
- large & 0 & 0 & 0 & 0 \\
- moderate & 4 & 21.1 & 0 & 0 \\
- small & 15 & 79.9 & 15 & 100 \\
Mother education level & & & & \\
- high & 6 & 31.6 & 1 & 6.7 \\
- secondary & 11 & 57.9 & 12 & 80.0 \\
- low & 2 & 10.5 & 2 & 13.3 \\
Family income per month & & & & \\
- high & 4 & 21.1 & 2 & 13.3 \\
- moderate & 15 & 78.9 & 10 & 66.7 \\
- low & 0 & 0 & 3 & 20.0 \\
\hline
\end{tabular}

Family income was significantly associated with maternal education $(\mathrm{P}<0.01)$, which means the higher education level of parents influenced to their family income. Level of income is a social indicator that can reflect the socioeconomic condition of a person. Father's education directly or indirectly will determine the economic state of the family, while the mother's education was the basic capital to strengthen the family economy. A higher level education become a determinant factor of unwanted pregnancies in Indonesia [7] and several studies have looked at whether educational level is associated with unplanned pregnancy [8,9]. A relationship between families' socioeconomic characteristics and toddler health may have substantial long-term consequences for individuals and entire societies [10].

\section{B. Heatlth and nutritional kwowledge}

Health and nutrition knowledge is the mother's cognitive abilities of the types and sources of nutrients, breast milk, complementary food, toddlers care and immunization.
TABLE II. HEALTH AND NUTRITIONAL KNOWLEDGE

\begin{tabular}{|c|c|c|c|c|}
\hline \multirow{2}{*}{ Socioeconomic aspects } & \multicolumn{2}{|c|}{$\begin{array}{l}\text { Unplanned } \\
\text { pregnancy }\end{array}$} & \multicolumn{2}{|c|}{$\begin{array}{c}\text { Planned } \\
\text { pregnancy }\end{array}$} \\
\hline & $n$ & $\%$ & $n$ & $\%$ \\
\hline \multicolumn{5}{|l|}{ Type and sources of nutrients } \\
\hline - poor & 1 & 5.3 & 1 & 6.7 \\
\hline - fair & 11 & 57.9 & 7 & 46.7 \\
\hline - good & 7 & 36.8 & 7 & 46.7 \\
\hline \multicolumn{5}{|l|}{ Breast milk } \\
\hline - poor & 2 & 10.5 & 3 & 20.0 \\
\hline - fair & 7 & 36.8 & 10 & 66.7 \\
\hline - good & 10 & 52.6 & 2 & 13.3 \\
\hline \multicolumn{5}{|l|}{ Complementary food } \\
\hline - poor & 11 & 57.9 & 10 & 66.7 \\
\hline - fair & 8 & 42.1 & 3 & 20.0 \\
\hline- good & 0 & 0 & 2 & 13.0 \\
\hline \multicolumn{5}{|l|}{ Toddler care } \\
\hline - poor & 0 & 0,0 & 1 & 6,7 \\
\hline - fair & 12 & 63,2 & 6 & 40,0 \\
\hline - good & 7 & 36,8 & 8 & 53,3 \\
\hline \multicolumn{5}{|l|}{ Imunisasi } \\
\hline - poor & 1 & 5,3 & 2 & 13,3 \\
\hline - fair & 8 & 42,1 & 10 & 66,7 \\
\hline$-\operatorname{good}$ & 10 & 52,6 & 3 & 20,0 \\
\hline \multicolumn{5}{|l|}{$\begin{array}{l}\text { Total knowledge in health and } \\
\text { nutrition }\end{array}$} \\
\hline - poor & 0 & 0,0 & 3 & 20,0 \\
\hline - fair & 12 & 63,2 & 9 & 60,0 \\
\hline - good & 7 & 36,8 & 3 & 20,0 \\
\hline
\end{tabular}

The assessment results of each aspect of health and nutrition knowledge showed that all respondents' nutrition knowledge are categorized as fair, except the aspect of complementary foods for breast milk was categorized poor $(61.8 \%)$. When observed carefully, the unplanned maternal mothers' education tends to be better than those who were not categorized as unplanned pregnancy. This shows that good health and nutrition knowledge was far in relation with mother's pregnancy status.

Based on spearman's correlation test, it shows a significance between nutrition knowledge and mother's education level $(\mathrm{P}<0.01)$, meaning that the higher mother's education, the better her nutrition knowledge and health. Some studies reported nutritional knowledge was independently associated with nutritional status but maternal education, on the other hand, was not found to be independently associated with nutritional status $[11,12]$.

\section{Mother's behavior in caring toddler health}

Mother's behavior in caring toddler health was assessed by conjoining scores of knowledge, behavior and mother's nutrition practice in term of breastfeeding, giving complementary foods, toddler health care, and immunization. Further, regarding to the findings revealed in this research, consuming behavior is categorized as good, fair, and poor. Generally, mother's behavior in caring toddler health is grouped as good (63.2\% of unplanned maternal mothers and $60 \%$ those who are not) and there is none who has poorcategorized behavior. 


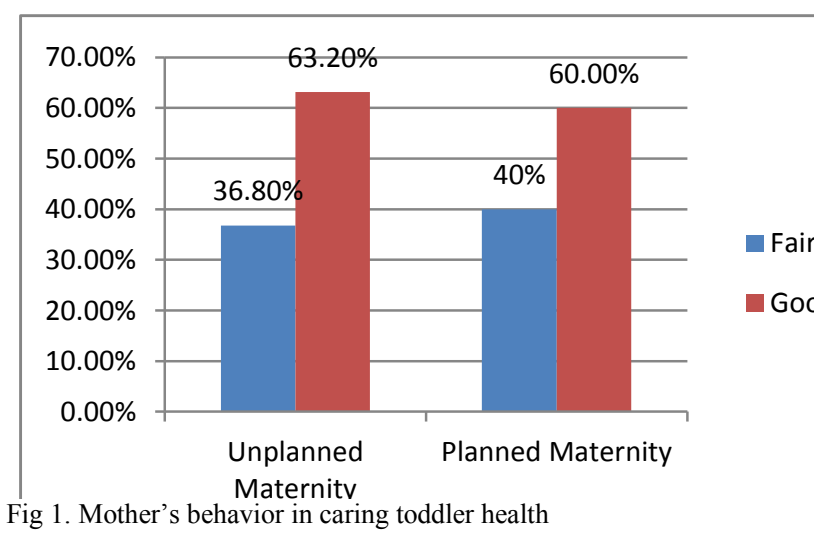

\section{1) Breastfeeding}

Giving a breast milk was given for toddler as known as a breastfeeding, of which was assessed by referring to nutrition knowledge in breastfeeding and mother's behavior and practice in breastfeeding. Table II showed the information of the respondents' behavior and practice in breastfeeding.

TABLE II. MOTHER'S BEHAVIOR AND PRACTICE IN BREASTFEEDING

\begin{tabular}{|l|c|c|c|c|}
\hline \multirow{2}{*}{ Breastfeeding } & \multicolumn{2}{|c|}{$\begin{array}{c}\text { Unplanned } \\
\text { Pregnancy }\end{array}$} & \multicolumn{2}{|c|}{$\begin{array}{c}\text { Planned } \\
\text { Pregnancy }\end{array}$} \\
\cline { 2 - 5 } & $\mathrm{n}$ & $\%$ & $\mathrm{n}$ & $\%$ \\
\hline Breastfeeding & & & & \\
- Yes & 14 & 73.7 & 14 & 93.3 \\
- No & 15 & 26.3 & 1 & 6.7 \\
Giving Colostrum & & & & \\
- Yes & 14 & 73.7 & 12 & 80.0 \\
- No & 5 & 26.3 & 3 & 20.0 \\
Breastfeeding Frequency & 5 & 26.3 & 3 & 20.0 \\
- <3 times & 0 & 0.0 & 0 & 0.0 \\
- 3-6 times per day & 14 & 73.3 & 12 & 80.0 \\
- Every time the toddler feels thirsty & & & & \\
Reasons of not doing Breastfeeding & 1 & 20.0 & 1 & 100.0 \\
- Lacks of breast milk production & 1 & 20.0 & 0 & 0.0 \\
- Toddler does not want it & 1 & 20.0 & 0 & 0.0 \\
- Mother's lung diseases & 2 & 40.0 & 0 & 0.0 \\
- Lacks of breast milk & & & & \\
\hline
\end{tabular}

Based on Table II, it indicated that the nutrition knowledge about breast milk had as good category for the unplanned pregnancy group $(52.6 \%)$, whereas, had fair for the planned pregnancy $(66.7 \%)$. There were six mothers who did not breastfeeding with $26 \%$ of those in unplanned pregnancy group. The reasons are various, including the lacks of breast milk production, their toddlers did not want to be breastfeed, mother's lung diseases, and lacks of breast milk.

In accordance with the result of Spearman's correlation test, there were a significant relation between mother's behavior and mother's knowledge about breast milk $(\mathrm{p}<0.05)$. Unplanned pregnancies are a risk factor for shorter breastfeeding durations $[6,10]$. The significant relation between nutritious behavior and nutrition knowledge were in line with Saaka [11] who stated that the higher knowledge in nutrition and health, it was possible to reduce the wrong nutrition practices and food dietaries. A person will had a good nutrition if she knew the foods consumed provides the required nutrients that can help the body growth, maintenance, and energy source optimally .

\section{2) Giving complementary foods}

Mother's behavior of giving appropriate complementary foods beside a breast milk for her toddler is determined at the glance of giving the complementary foods, the types, and the frequency of the foods themselves. This research finds the interval times of giving complementary foods ranging from two to seven months with the first time of feeding is less than six month experienced by seven mothers. This number is a bit more than mothers in unplanned pregnancy group which is only six persons.

The types of complementary foods given to toddler aged six month or higher are various; 22 mothers give a softened banana, 4 mothers give milk porridge, and only one mother gives rice porridge. The most given vegetables are spinach and carrot, while the fruits consist of banana, papaya and orange. Table III shows the information of mothers giving the complementary foods.

TABLE III. MOTHER'S BEHAVIOR GIVING COMPLEMENTARY

\begin{tabular}{|c|c|c|c|c|}
\hline FOOD & & & & \\
\hline \multirow[t]{2}{*}{ Giving Complementary Foods } & \multicolumn{2}{|c|}{$\begin{array}{l}\text { Unplanned } \\
\text { Pregnancy }\end{array}$} & \multicolumn{2}{|c|}{$\begin{array}{l}\text { Planned } \\
\text { Pregnancy }\end{array}$} \\
\hline & $\mathrm{n}$ & $\%$ & $\mathrm{n}$ & $\%$ \\
\hline \multicolumn{5}{|l|}{$\begin{array}{l}\text { The first time of giving complementary } \\
\text { foods }\end{array}$} \\
\hline$->6$ months & 6 & 31.6 & 1 & 6.7 \\
\hline$-<6$ months & 13 & 68.4 & 14 & 93.9 \\
\hline $\begin{array}{l}\text { The types of the first-given complementary } \\
\text { foods }\end{array}$ & & & & \\
\hline - puree of banana & 2 & 33.3 & 0 & 0.0 \\
\hline - milk porridge & 4 & 66.7 & 0 & 0.0 \\
\hline - rice porridge & 0 & 0.0 & 1 & 100 \\
\hline The frequency of giving the foods & & & & \\
\hline$-<3$ times per day & 7 & 36.8 & 9 & 69.2 \\
\hline - 3 times per day & 7 & 36.8 & 3 & 23.1 \\
\hline - $>3$ times per day & 5 & 26.3 & 1 & 7.7 \\
\hline
\end{tabular}

Table III indicated that there was 31.6 percent unplanned pregnancy giving complementary food before 6 months. WHO recommended that complementary foods be introduced at 6 month of age $(180 \mathrm{~d})$ [13]. Saldiva [14] and Caroli [15] showed earlier introduction of complementary foods has been associated with lower levels of family income and maternal education.

\section{3) Toddler health care}

A routine toddler health care done by mothers consists of measuring the toddler's weight and height. Based on the interview results and notes, most mothers did measuring toddler's weight and height once a month in the nearest local government clinic. All mothers also choose to take their sick children to local government clinic or hospital, instead of gambling with self-caring or with doubtful private clinic.

The results has shown that mother's behavior in caring her toddler had categorized as good. The analysis of Spearman's correlation test indicates that there were a significant relation between mother's behavior and her knowledge in caring the toddler $(\mathrm{p}<0.05)$. Moreover, the higher mother's knowledge, the better she cares her toddler. 
The routine of going to the local government clinic is a manifestation of mother's awareness in well caring toddler health [16].

\section{4) Immunization}

Giving an immunization is a form of mother's care about her toddler health. Generally, a mother give the first immunization when her toddler is between zero to one month. The first immunization type given is BCG in either local clinic $(94.1 \%)$ or midwife $(5.9 \%)$. Revealed in this research, there is no difference between the two groups of pregnancy type in relation with giving immunization, which is all good. However, this circumstance depends on whether the mother also has a good knowledge.

\section{The Relation between mother's behavior in caring toddler health and pregnancy status}

The mother's behavior categorized in unplanned pregnancy in term of breastfeeding and giving complementary foods was better than those in planned pregnancy group. Meanwhile, there was no difference on the aspects of giving immunization and health care between both groups. In connection with the result of Spearman's correlation test, there is no relation between mother's behavior in caring toddler health and mother's pregnancy status. This situation is relevant to Chinebuah [10] who stated that mother's pregnancy status much more relates with toddler breastfeeding. This issue may be caused by most unplanned maternal mothers still live with their big family in caring the toddlers.

\section{CONCLUSION AND SUGGESTION}

\section{A. Conclusion}

Most mothers generally have small family members with only possessing high school diploma and are currently jobless, yet their family income is below the minimum standard of living. Mothers' nutrition and health knowledge are categorized as fair. The mothers' behaviors of caring toddler health are categorized as good; $63.2 \%$ of the unplanned pregnancy group and $60 \%$ of those in another group). Moreover, there is a tendency that mothers in the unplanned pregnancy group give breast milk and the complementary foods better than those in the planned pregnancy group. However, there is no exact relation between mother's behavior in caring toddler health and pregnancy status.

\section{B. Suggestion}

The research suggests that, first, to all parents, it is important to give total care, monitoring and good nutrition knowledge for their children in order to reduce the number of unplanned pregnancy. Second, government health office, higher education institutions, and NGOs need to make young mothers a salient focus of health care program, to achieve qualified young generations. Moreover, this collaboration can be an effort to respond any effects of the unplanned pregnancy.

\section{REFERENCES}

[1] M.T. Kinsella, and Catherine Monk, " Impact of maternal stress, depression and anxiety on fetal neurobehavioral development," Clin Obstet Gynecol, vol. 52, pp. 425-440, September 2009.

[2] Dunkel Schetter C, and Tanner L, "Anxiety, depression and stress in pregnancy: implications for mothers, children, research, and practice," Curr Opin Psychiatry, vol. 25, pp. 141-148, March 2012.

[3] M. Najafian, K.B. Karami, M. Cheraghi, and R. Mohammad Jafari, "Prevalence of and Some Factors Relating with Unwanted Pregnancy,in Ahwaz City", Iran, 2010," ISRN Obstetrics and Gynecology, vol. 2011 pp. 1-4, October 2011.

[4] A Glasier, A.M Gulmezoglu, G.P. Schmid, C.G. Moreno, and P.F. Van Look, "Sexual and reproductive health: a matter of life and death," The Lancet Sexual and Reproductive Health Series, vol. 368, pp. 1595-1607, October 2006.

[5] Badan Pusat Statistik (BPS) dan MacroInternational." Survei Demografi dan Kesehatan Indonesia 2012". Calverton, maryland, USA : BPS dan Macro International.2012

[6] R. Perez-Escamilla, J.A. Cobas, H. Balcazar, and M.A. Benin, "Specifying the antecedents of breastfeeding duration in Peru through a structural equation mode," Public Health Nutrition, vol. 2, pp. 461-467. June 1999.

[7] I. Saptarini, and Suparmi, "Determinan kehamilan tidak diinginkan di Indonesia (Analisis data sekunder Riskesdas 2013)," Jurnal Kesehatan Reproduksi, vol. 7, no. 1, pp. 15-24, April 2016.

[8] C. Calvert, K. Baisley, A.M. Doyle, K. Maganja, J. Changalucha, D.W. Jones, R.J. Hayes, D.A. Ross, "Risk factors for unplanned pregnancy among young women in Tanzania," Journal Family Planning Reproductive Health Care, vol 39, pp. 1-12. May 2013

[9] L.M. Kuroki, J.E. Allsworth, C.A. Redding, et al, "Is a previous unplanned pregnancy a risk factor for a subsequent unplanned pregnancy?" Am J Obstet Gynecol, pp. 511-517. 2008.

[10] Chinebuah, Bridget and Rafael Perez-Escamilla..”Unplanned Pregnancies are Associated with Less Likelihood of prolonged Breastfeeding Among Primiparous woman in Ghana". Journal of Nutrition, vol. 131. pp. 1247-1249. Januari 2001

[11] M. Saaka," Relationship between Mothers' Nutritional Knowledge in Childcare Practices and the Growth of Children Living in Impoverished Rural Communities," J. Health Popul. Nutr, vol. 32, pp. 237-248, June 2014.

[12] C.G. Victora, A. Wagstaff, J.A.Schellenberg, D. Gwatkin, M. Claeson, J-P. Habicht," Applying an equity lens to child health and mortality: more of the same is not enough. The Lancet, vol 362, pp 233-241, July 2003.

[13] WHO. Global strategy for infant and young child feeding. Geneva (Switzerland): WHO; 2003.

[14] S.R. Saldiva, M.M. Escuder, L. Mondini, R.B. Levy, S.I. Venancio," Feeding habits of children aged 6 to 12 months and associated maternal factors," J. Pediatr (Rio J), vol. 83, pp. 53-58. 2007.

[15] M. Caroli M, R.M. Mele, M.A. Tomaselli, M. Cammisa, F. Longo, E. Attolini,'Complementary feeding patterns in Europe with a special focus on Italy," Nutr Metab Cardiovasc Dis, vol. 22, pp. 813-818, 2012.

[16] S.N.L. Sakbaniyah, S. Herawati, D. N. Mustika,'Hubungan pengetahuan ibu balita dengan kepatuhan kunjugan balita ke posyandu di desa Sumberejo kecamatan Mranggen kabupaten Demak. http:jurnal.unimus.ac.id pp. 39-44, 2013 